\title{
Instituto Brasileiro de Relações Internacionais: 50 anos de um grande empreendimento intelectual
}

PAULO ROBERTO DE ALMEIDA*

Em 27 de janeiro de 1954, o Palácio Itamaraty do Rio de Janeiro acolheu um grupo de personalidades públicas interessadas na política externa brasileira e nas relaçôes internacionais de modo geral. Eles, um grupo de funcionários governamentais, incluindo diplomatas, e de representantes da vida civil e da iniciativa privada, decidiram congregar esforços para aprofundar no país o debate em torno dessas questóes e tornar o processo decisório em matérias diplomáticas mais inclusivo e mais diversificado. O Instituto Brasileiro de Relações Internacionais foi o resultado desse encontro: o IBRI foi definido como uma sociedade civil com finalidades culturais, com o objetivo de "realizar, promover e incentivar estudos sobre problemas internacionais, especialmente os de interesse para o Brasil", e pode-se dizer que seus objetivos originais foram amplamente cumpridos, como demonstrado no meio século decorrido desde então.

$\mathrm{O}$ Brasil vivia então uma fase de relativo otimismo quanto às possibilidades de desenvolvimento econômico e de inserção internacional. Ainda éramos um "país essencialmente agrícola", exportador de commodities agrícolas - com o café representando mais de $60 \%$ da pauta

* Diplomata de carreira e Doutor em Ciências Sociais. As opiniões expressas no presente texto são exclusivamente as de seu autor. 
exportadora - e de minério de ferro, mas as perspectivas de industrialização estavam sendo construídas, tanto via planejamento e monitoramento governamental quanto por meio dos investimentos privados, inclusive estrangeiro. Nossa participação no sistema internacional do pósguerra era relativamente limitada, mas ainda assim intensa: tínhamos mandado tropas combater no teatro de guerra europeu, pensando com isso assegurar um papel relevante para o país na ordem política que se estava desenhando nas reuniōes multilaterais sob liderança dos Estados Unidos, e tínhamos estado "presentes na criação" dos mais importantes organismos intergovernamentais então estabelecidos (tanto em Bretton Woods, ainda em plena guerra, e no Gatt, em 1947, como nos primeiros acordos de matérias primas dos quais resultariam as organizações para café e açúcar). Tínhamos prudentemente recusado enviar tropas para atuar, sob comando americano, na guerra da Coréia, mas não hesitamos em participar das tropas onusianas de manutenção de paz por ocasião da crise de Suez, em 1956.

Nossa participação no comércio internacional era bem mais importante do que atualmente, mas isso representava o reflexo do afastamento europeu dos circuitos comerciais internacionais, em conseqüência da guerra e da reconstrução, e do alto preço das matérias primas num contexto de acirramento da Guerra Fria. O Brasil não soube aproveitar todas as oportunidades oferecidas pela expansão extraordinária do comércio internacional no decorrer dos "trinta gloriosos anos" de crescimento contínuo da economia mundial, mas ele conseguiu, ao longo do Plano de Metas do governo Juscelino Kubitschek (1956-1961), atrair capitais externos em nível suficiente para impulsionar, de modo significativo, seu processo industrializador, logrando construir uma das poucas economias modernas do mundo em desenvolvimento. $\mathrm{O}$ papel do Estado foi ampliado e reforçado naquelas áreas de infra-estrutura e de indústria de base, assim como na pesquisa científica de ponta datam dessa época, por exemplo, os primeiros avanços em matéria de aproveitamento da energia nuclear - mas deixou bastante a desejar no terreno da educação fundamental. No plano da política externa, especificamente, começou a ser desenhado o contorno do que mais tarde viria a ser conhecido como a "política externa independente", um dos eixos fundamentais da política brasileira no início dos anos 60 . 
O IBRI, por meio de seus membros, contribuiu de modo insofismável para a elevação dos padrões de análise, diagnóstico e formulação de políticas alternativas na frente externa. Um de seus membros mais ativos, Cleantho de Paiva Leite, participou de algumas das iniciativas diplomáticas da presidência Kubitschek, entre elas a Operação Pan-Americana, da qual resultaria, pouco adiante, o Banco Interamericano de Desenvolvimento e, de certo modo, a própria Aliança para o Progresso, lançada pelo presidente John Kennedy. Cleantho tornou-se, logo em seguida, um dos diretores brasileiros no BID, continuando, paralelamente, seu trabalho de promoção do IBRI e de seus objetivos de disseminação pública dos debates sobre política internacional do Brasil.

Em 1958, justamente, no âmbito do seu plano de trabalho, que incluía um "programa de publicações", o IBRI lançou a Revista Brasileira de Politica Internacional (RBPI) que, durante seus 35 anos de vida no Rio de Janeiro, em especial sob a coordenação de Cleantho de Paiva Leite, desempenhou um importante papel na difusão de matérias e documentos relativos à política internacional, às relações exteriores do Brasil, bem como ao próprio pensamento e prática brasileira em temas de política externa. Decana das revistas brasileiras de relações internacionais, a $R B P I$ preenche um papel de relevo em nossa cultura política e acadêmica, reunindo, nas dezenas de volumes editados ao longo de quase meio século, um somatório extremamente rico e variado de informações, análises e documentos sobre a política internacional e as relações exteriores do Brasil. Ela constitui, assim, uma "memória escrita" privilegiada sobre a política externa brasileira e uma fonte de referência indispensável para toda pesquisa acadêmica sobre as relações internacionais nas últimas quatro décadas e meia.

Em 1993, no seguimento da morte de Cleantho de Paiva Leite e por iniciativa de um grupo de diplomatas e acadêmicos, a $R B P I$ foi transferida para Brasília, como forma de assegurar sua sobrevivência e continuidade, o que foi exitosamente cumprido. Desde então ela tem sido regularmente publicada. O próprio IBRI foi reestruturado e reconstituído em Brasília, dedicando-se, na modéstia de seus meios, às tarefas de administração, confecção e circulação da RBPI, ademais de uma série de outras iniciativas, como seminários e edição de livros da área de relações internacionais. 
Assinaram a ata de reconstituição do IBRI em Brasília o embaixador Sérgio Guarischi Bath, o ministro da carreira diplomática Adolf Libert Westphalen, os professores José Carlos Brandi Aleixo, Antonio Augusto Cançado Trindade, Amado Luiz Cervo, Alcides Costa Vaz e Luciara Silveira de Aragão e Frota e o conselheiro Paulo Roberto de Almeida, do Itamaraty. O IBRI teve como seu primeiro diretor em Brasília o professor José Carlos Brandi Aleixo (1993-1997), hoje seu presidente de honra, seguido pelo conselheiro, depois ministro, Paulo Roberto de Almeida (1997-1999) e, atualmente, pelo professor José Flávio Sombra Saraiva (desde 1999). A RBPI, por sua vez, foi colocada sob a direção editorial do professor Amado Luiz Cervo, da Universidade de Brasília (UnB), em seus primeiros dez anos de Brasília, após o que foi escolhido o professor Antônio Carlos Lessa para dar seguimento a essa tarefa. Vem atuando como seu editor adjunto o diplomata Paulo Roberto de Almeida.

A reestruturação do IBRI, em Brasília, ofereceu oportunidade de ser elaborado amplo programa de trabalho, compreendendo o reforço de suas atividades acadêmicas e o estabelecimento de vínculos com entidades congêneres, do Brasil e do exterior. Sua reativação enquanto centro de pesquisas, encontros e debates, bem como o processo de modernização editorial e de circulação ampliada da RBPI, complementado pela edição de livros e por webpage do IBRI vem constituir-se em importante fator de consolidação do campo das relações internacionais no Brasil.

Novembro de 2004 